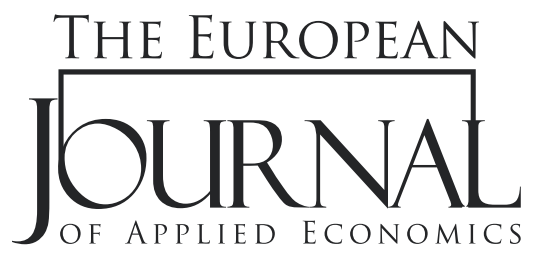

EJAE 2018, 15(1): 1-19

ISSN 2406-2588

UDK: $331.53: 34(71)$

DOI: 10.5937/EJAE15-15824

Original paper/Originalni naučni rad

\title{
THE INDICATOR OF EMPLOYMENT PROTECTION LEGISLATION FOR CANADA
}

\author{
Samir Amine*, Véra-Line Montreuil \\ Université du Québec en Outaouais, Canada
}

\begin{abstract}
:
Since the early 1990s, employment protection legislation (EPL) has become a concern for public policy makers in particular with respect to its impact on unemployment and productivity. This topic arose pronounced attention of international organizations. Indeed, these institutions have built analytical models to assess the strictness of EPL in different countries, but we find that these models are sometimes incomplete despite the abundance of information they provide. The purpose of this article is to propose the introduction of new elements to the Organization for Economic Co-operation and Development (OECD) analysis model based on the Canadian experience. We, thus, propose to adjust the synthetic indicator of EPL for Canada taking into account local specificities not taken into consideration by the OECD.
\end{abstract}

\section{Article info:}

Received: November 25, 2017

Correction: December 12, 2017

Accepted: December 12, 2017

\section{Keywords:}

Employment Protection Legislation, Synthetic Indicator,

OECD,

Voluntary Departure, Work-Sharing.

\section{INTRODUCTION}

The employment protection legislation (EPL) is at the heart of a debate in the field of industrial relations and labour law related to the flexibility-security dilemma. According to the Organization for Economic Co-operation and Development (OECD):

"employment protection refers both to regulations concerning hiring (e.g. rules favouring disadvantaged groups, conditions for using temporary or fixed-term contracts, training requirements) and firing (e.g. redundancy procedures, mandated prenotification periods and severance payments, special requirements for collective dismissals and short-time work schemes). Various institutional arrangements can provide employment protection: the private market, labour legislation, collective bargaining agreements and, not the least, court interpretation of legislative and contractual provisions" (p. 50: OECD, 1990).

In the light of this definition we can therefore assume that EPL refers to the rules surrounding employment adjustment. 
Since the last financial crisis, many countries have implemented reforms to modify the strictness of EPL in order to enhance flexibility in difficult circumstances. In 2010, Greece, Portugal, and Spain reduced severance pay in the case of dismissal for regular contracts and also reduced the strictness of regulation regarding collective dismissals (OECD, 2012; Martin, 2013). In Italy, the regulations on temporary contracts have been reduced (Martin, 2013). Similarly, in 2008, France implemented a system to end a job contract through mutual consent between the employer and the worker (OECD, 2012). Other measures to make the labour market more flexible were adopted in 2016 under the "El KhomriLabour Law". In the same context, other proposals have been made, such as the introduction of taxation on redundancy named as a "bonus-malus" system, currently in force in the United States and built around the principle that firms must contribute to the unemployment insurance according to their history of layoffs (Amine et al., 2007; Blanchard \& Tirole, 2003).

In the literature, several studies examined the effects and the analysis models of EPL (see OECD, 1993; International Labour Organization, 2013). However, only a few of them seem to emphasize the need for improvements in these models to reflect precisely the context of each country. The model that has retained our attention is the OECD model, built since 1993. This model covers the G20 countries and has 21 weighted analysis criteria to allow international comparisons in terms of employment protection legislation. OECD model has received much attention from international researchers, labour lawyers and policy makers who have been trying to better understand the level of EPL strictness in different countries and its impact on the labour market. However, despite the abundance of information it provides, we believe that this model needs improvement in order to provide a full and accurate portrait of employment protection legislation for each country. Therefore, based on the Canadian experience, this article suggests adding two essential sub-components to the OECD model so as to expand its scope: the voluntary departure plan and the work- sharing. We also suggest reviewing the weighting of the components in order to properly reflect the dynamics of labour market. Our results indicate that the consideration of new sub-components and the review of the weighting door slightly upward Canadian synthetic indicator. This observation thus leads us to believe that the mere evaluation of the constraints imposed on the employer in terms of redundancies and the use of temporary contracts, may underestimate the degree of strictness of EPL in Canada, when we do not take into account other employment adjustment mechanisms such as voluntary departure plan and work-sharing.

We believe that the addition of these elements will bring more details and nuances in terms of global comparisons between Canada and the United States, that are often perceived as being similar despite the differences in the configuration of their social and legal protection systems. Besides, Block (2007) highlights the differences between the rigour of Canadian and US labour standards by creating indicators, including standards that could force employers in their adjustment to the workforce. Moreover, since OECD model is an international framework whose main purpose is to help and guide policy makers and labour lawyers from various governments to introduce new reforms or apply changes to public policies and laws in the field of labour, we believe that the adjustments proposed in this article will help this model to reflect more adequately the reality of the EPL strictness in countries.

Although we have chosen Canada as a study case, voluntary departure plans can be found in different countries (e.g. France and the United States). We can also find work-sharing in France, Italy, Germany, Belgium, Portugal and Australia. Therefore, Canada is an interesting case since our proposals can lead to revising the EPL indicators of several countries that have those two workforce adjustment mechanisms.

In fact, voluntary departure is often seen as an alternative or complementary mechanism to economic redundancies. The voluntary departure is usually a cheaper and less restrictive option for employers 
than proceeding directly to layoffs despite sometimes severance pay can be high. Indeed, the risk of litigation in the courts decreases when the employer initiates such a measure and, generally, it imposes less of legal obligations. However, the legal obligations associated to voluntary departure may be different depending on the country (Bourguignon \& Garaudel, 2015; Niel \& Hautefort, 2015). In addition, since this practice seems to become more and more common, the integration of this component in the OECD model becomes essential.

As for work-sharing, it is a practice that is generally implemented with the aim to avoid layoffs or redundancies when a firm is facing economic downturns. Essentially, the employer asks several of its employees to temporarily reduce their working hours for a given period or, in some cases, rather than just dismiss the employees, the employer may temporarily suspend its activities. This mechanism is also called "partial/technical unemployment" or "partial activity" (Bisignano, 2014; Werner \& Marx, 2009).

In brief, we support that these two mechanisms should be included in the OECD model since they allow employers to adjust their workforce in the same manner as firing and hiring. Furthermore, they protect workers from job losses or at least mitigate its probability to occur. As we will see, these mechanisms have a different level of strictness (constraints), depending on the country.

This article is organized as follows. The second section will present the literature review related to the EPL. Afterwards, the methodology will be the subject of the third section by addressing the limitations of existing work and presenting our proposals for the introduction of specific variables. The results of our analysis and concluding remarks will be discussed respectively in the fourth and fifth sections.

\section{LITERATURE REVIEW}

\section{Different analysis models of Employment Legislation since 1990s}

In the early 1990s, scientific community realized that there was a clear variation among countries regarding their employment protection legislation. Indeed, the literature found that Anglo-Saxon countries seemed to have a much less rigid regulation than that observed in Europe as a whole and these differences could have a different impact on the labour market: presence or absence of market rigidification through a high unemployment rate and stagnation in job creation, also known as institutional sclerosis (Deslauriers, Dostie \& Gagné, 2009; OECD, 1999). Thus, countries with a strict EPL seemed to have a labour market suffering from institutional sclerosis whereas those with very low EPL did not appear to exhibit symptoms related to this phenomenon. The need to measure these laws in order to make international comparisons was thus born, as was the development of several research studies to clarify the effects of this legislation on labour market dynamics.

Before presenting the OECD model, which is at the heart of this article, it is important to briefly mention that two other international organizations had developed their own employment protection legislation model.

First, the ILO had focused its analysis of the EPL in seven specific categories of provisions in 90 countries: type of employment contract, substantive requirements for dismissals, procedural requirements for individual dismissals, procedural requirements for collective dismissals for economic reasons, severance pay and redundancy payment and avenues for redress which are presented in table 1.

However, it should be noted that only workers regulated by federal legislation were considered in the analysis conducted in 2012 for Canada by the ILO. This analysis excludes all workers covered by provincial labour laws (about 90\% of Canadians workers) (ILO, 2013). Thus, while the ILO database 
is rich in information for the lawyers and policy makers, it should be borne in mind that for Canada, this database does not fully reflect the full reality of employment protection legislation.

\begin{tabular}{|c|c|c|}
\hline Category & \multicolumn{2}{|c|}{ Provision } \\
\hline $\begin{array}{l}\text { Type of } \\
\text { employment } \\
\text { contract }\end{array}$ & - Maximum probationary period & - Use of fixed-term contract \\
\hline $\begin{array}{l}\text { Substantive } \\
\text { requirements for } \\
\text { dismissals }\end{array}$ & $\begin{array}{l}\text { - Obligation to provide reasons to the } \\
\text { employee } \\
\text { - Valid grounds }\end{array}$ & $\begin{array}{l}\text { - Prohibited grounds } \\
\text { - Workers enjoying special protection }\end{array}$ \\
\hline $\begin{array}{l}\text { Procedural } \\
\text { requirements for } \\
\text { individual } \\
\text { dismissals }\end{array}$ & $\begin{array}{l}\text { - Notification to the worker to be dismissed } \\
\text { - Notice period } \\
\text { - Pay in lieu of notice } \\
\text { - Notification to the public administration }\end{array}$ & $\begin{array}{l}\text { - Notification to workers' representatives } \\
\text { - Approval by public administration or } \\
\text { - Apdicial bodies } \\
\text { - Approval by workers' representatives }\end{array}$ \\
\hline $\begin{array}{l}\text { Procedural } \\
\text { requirements } \\
\text { for collective } \\
\text { dismissals for } \\
\text { economic reasons }\end{array}$ & $\begin{array}{l}\text { - Definition of collective dismissal } \\
\text { - Prior consultations with trade unions } \\
\text { - Notification to the public administration } \\
\text { - Notification to workers' representatives } \\
\text { - Approval by public administration or } \\
\text { judicial bodies }\end{array}$ & $\begin{array}{l}\text { - Approval by workers' representatives } \\
\text { - Eriority rules for collective dismissals } \\
\text { natives to dismissal } \\
\text { - Priority rules for reemployment }\end{array}$ \\
\hline $\begin{array}{l}\text { Severance pay } \\
\text { and redundancy } \\
\text { payment }\end{array}$ & - Severance pay & - Redundancy payment \\
\hline $\begin{array}{l}\text { Avenues for } \\
\text { redress }\end{array}$ & $\begin{array}{l}\text { Compensation for unfair dismissal - free } \\
\text { determination by court } \\
\text { - Compensation for unfair dismissal - le- } \\
\text { gal limits } \\
\text { - Reinstatement }\end{array}$ & $\begin{array}{l}\text { - Preliminary mandatory conciliation } \\
\text { - Competent court(s) or tribunal(s) } \\
\text { - Existing arbitration }\end{array}$ \\
\hline
\end{tabular}

Table 1. Employment protection legislation (EPL)

Source: Data from International Labour Organization, 2013

Second, the World Bank Group (Doing Business) also addressed the issue of strict regulation of the labour market by developing its own model of analysis. Thus, Doing Business evaluates the flexibility of a country's regulation around three areas: the difficulty of recruiting, the rigidity of working hours and the difficulty of dismissing. It also assesses the cost of redundancy and, in 2015, new variables related to the social protection system and the existence of labor dispute tribunals was added.

However, the analysis of Doing Business is based on certain assumptions that cannot fully represent the reality of all the regulations of a country affecting employment protection. Indeed, in the analysis model, it is postulated that the worker is a full-time cashier in a supermarket and is not a member of a union unless it is an obligation. In addition, it is assumed that the company under study runs a supermarket or food store in the largest business metropolis of the economy and holds 60 employees (World Bank Group, 2016). As a result, these limitations on the analytical framework greatly limit its ability to generalize its results to a national economy, especially to certain countries, such as Canada, where the majority of the labour law is under the jurisdiction of the provinces and territories. That 
said, the Doing Business model becomes particularly useful and relevant when we want to look at the issue of employment legislation in the food sector specifically, but more difficult when we want to get a portrait of a national situation as a whole.

\begin{tabular}{|c|c|c|}
\hline \multicolumn{3}{|c|}{ Flexibility } \\
\hline Difficulty of hiring & Rigidity of hours & Difficulty of redundancy \\
\hline $\begin{array}{l}\text { Fixed-term contracts prohibited } \\
\text { for permanent tasks } \\
\text { - Maximum length of fixed-term } \\
\text { contracts } \\
\text { - Minimum wage for a full-time } \\
\text { worker } \\
\text { Ratio of minimum wage to value } \\
\text { added per worker }\end{array}$ & $\begin{array}{l}\text { - } 50 \text { hours workweek allowed } \\
\text { - Maximum working days per week } \\
\text { - Premium for night work } \\
\text { - Premium for work on weekly rest } \\
\text { day } \\
\text { - Major restrictions on night work } \\
\text { - Major restrictions on weekly holi- } \\
\text { day work } \\
\text { - Paid annual leave }\end{array}$ & $\begin{array}{l}\text { Maximum length of probation- } \\
\text { ary period } \\
\text { - Dismissal due to redundancy al- } \\
\text { lowed by law } \\
\text { - Third-party notification if } 1 \text { work- } \\
\text { er is dismissed } \\
\text { - Third-party approval if } 1 \text { worker } \\
\text { is dismissed } \\
\text { - Third-party notification if } 9 \text { work- } \\
\text { ers are dismissed } \\
\text { - Third-party approval if } 9 \text { work- } \\
\text { ers are dismissed } \\
\text { - Retraining or reassignment } \\
\text { - Priority rules for redundancies } \\
\text { - Priority rules for reemployment }\end{array}$ \\
\hline \multicolumn{3}{|c|}{ Redundancy cost } \\
\hline \multicolumn{3}{|c|}{$\begin{array}{l}\text { - Notice period for redundancy dismissal } \\
\text { - Severance pay for redundancy dismissal }\end{array}$} \\
\hline \multicolumn{3}{|c|}{ New variables } \\
\hline \multicolumn{3}{|c|}{$\begin{array}{l}\text { - Unemployment protection scheme } \\
\text { - Health insurance for permanent employees } \\
\text { - Courts or court sections specializing in labour disputes }\end{array}$} \\
\hline
\end{tabular}

Table 2. Labour Market Regulation - Doing Business

Source: Data from World Bank Group, 2015 (p.232)

Finally, the OECD, on its side, has built an analytical framework for measuring the degree of EPL strictness through an analysis of the rules governing the dismissal and recruitment of temporary employees. It has developed its model with a particular focus on the cost of adjusting the workforce to employers that can sometimes be excessive (OECD, 2013). Moreover, OECD warns the researcher who wants to use its model for other purposes that the model aims to study, stressing that "by contrast, the effectiveness of legislation in protecting workers might not be well captured by these indicators. Therefore, care must be exerted when not using these indicators as measures of legislation-induced costs for employers making staffing changes." (p.74: OCDE, 2013).

Certainly, this model has its limits. The weighting of the criteria in the OECD grid in the EPL synthetic indicators seems to be established on a universal basis and, therefore, seems not to be modulated according to the composition of the labour market in each country. Indeed, the weight of the component of regular contracts is the same as temporary contracts (5/12) and collective dismissals represent $2 / 12$ of the EPL indicator of all countries. These non-indexed weights on the labour market reality 
can lead to a biased assessment of the strictness of EPL in any country analysed (Kirat, 2006; Martin et al., 2013; Niel, 2009; Niel \& Hautefort, 2015). Furthermore, OECD mentions that "a re-assessment of the scoring grid for each component, as well as of the weights used to aggregate them, is probably warranted, but it is left for future work" (p. 108). Moreover, Martin, Du Marais and Dehaze (2013) note that the current synthetic EPL indicators do not include new employment adjustment modes such as voluntary departure plan. Along with these authors we also believe, based on Canadian experience, that it is necessary to incorporatethe voluntary departure plan and work-sharing into the evaluation of EPL in order to provide a more inclusive and complete portrait of the employment protection legislation.

It should be noted, however, that over time, the OECD has made adjustments to its model following proposals made within the scientific community. Specifically, it included the content of collective agreements and jurisprudence in the evaluation of the indicator (OECD, 2013; Venn, 2009). Moreover, in its detailed analysis, for example for Canada, disparities in employment protection legislation within provinces are now taken into account (OECD, 2014).

Therefore, the purpose of this paper is to address some of these limitations, especially those relating to the distribution of weights within the model and the integration of some mechanisms that allow employers to adjust their labour force when they faced a decline in productivity, an economic shock, etc. Consequently, the originality of this article lies in the fact that it does not merely provide a criticism of the OECD model but, through the analysis of the case of Canada, suggests adjustments in order to provide a more precise and representative portrait of the legislative and administrative realities of the countries. Whereas the OECD provides a quantitative evaluation of EPL, it is important to note that some authors (Deslauriers et al., 2009) have stressed the limits of quantifying employment protection legislation for international comparisons. These authors argue, in particular, that it is difficult to compare EPL indicators across countries, as this would hardly reflect the social context, culture and legal procedures unique to each country. These procedures may, in fact, be more or less long and tedious depending on the country in which we find ourselves. However, Adams et al. (2017) point out:

"A somewhat different argument about the limits of quantitative approaches to legal research turns on the view that mathematical models assume a rigidly deterministic relationship between variables which is at odds with the open, dynamic nature of social systems in general, and a fortiori with the opentextured and indeterminate nature of legal rules, not least those of labour law. This is a more weighty objection to quantitative legal research, but we think that would be going much too far to take it to the point of rejecting all uses of statistical and mathematical approaches to empirical legal analysis. The issue, rather, is to understand what quantitative methods can achieve, and not to push them beyond their inherent limits" (p.63).

While some papers criticize such a model for focusing primarily on the dismissal (individual and collective) and for using temporary contracts, thus restricting the scope of its definition of employment protection (Deslauriers et al., 2009), the OECD model remains highly developed and covers all G20 countries.

Indeed, the OECD studies three types of dispositions. First, there are the rules governing the protection of regular workers in cases of individual dismissal. This component is divided into sub-components as shown in table 1: procedural inconveniences, notice and severance pay for no-fault individual dismissal, difficulty of dismissal. Thus, in order to assess the strictness of this EPL component, OECD examines the clauses relating to notification procedures, the delay to start a notice, the definition of unfair dismissal, etc. The second EPL component is the regulation of temporary contracts which is divided into two sub-components as also shown in table 1: fixed-term contracts and temporary work 
agency employment (interim). For this component, the OECD assesses, for example, the maximum number of successive contracts that an organization can undertake, the maximum cumulated duration of temporary work, etc. Finally, the third component represents the obligations associated with collective dismissal. In assessing this component, OECD relies on the definition of collective dismissal, additional notification obligations, other special costs to employers, etc. (OECD, 2014). In addition, each of the 21 criteria used to analyze the rigour of EPL is weighted to try to reflect as closely as possible the weight of each component in regulating the behavior of actors in society (see table 3 ).

\begin{tabular}{|c|c|c|c|}
\hline \multicolumn{3}{|c|}{ Synthetic Indicator } & Weighting \\
\hline \multirow{13}{*}{$\begin{array}{l}\text { Regular } \\
\text { contract }\end{array}$} & \multirow{2}{*}{ Procedural inconveniences } & Notification procedures & $1 / 2$ \\
\hline & & Delay to start a notice & $1 / 2$ \\
\hline & \multirow{6}{*}{$\begin{array}{l}\text { Notice and severance pay } \\
\text { for individual dismissal } \\
\text { without fault }\end{array}$} & Notice period after 9 months & $1 / 7$ \\
\hline & & Notice period after 4 years & $1 / 7$ \\
\hline & & Notice period after 20 years & $1 / 7$ \\
\hline & & Severance pay after 9 months & $4 / 21$ \\
\hline & & Severance pay after 4 years & $4 / 21$ \\
\hline & & Severance pay after 20 years & $4 / 21$ \\
\hline & \multirow{5}{*}{ Difficulty of dismissal } & Definition of unfair dismissal & $1 / 5$ \\
\hline & & Duration of the trial period & $1 / 5$ \\
\hline & & Compensation & $1 / 5$ \\
\hline & & Reinstatement & $1 / 5$ \\
\hline & & Maximum time for claim & $1 / 5$ \\
\hline \multirow{8}{*}{$\begin{array}{l}\text { Temporary } \\
\text { contract }\end{array}$} & \multirow{3}{*}{ Fixed-term contracts (FTC) } & Valid cases for use of FTCs & $1 / 2$ \\
\hline & & Maximum number of successive FTCs & $1 / 4$ \\
\hline & & Maximum cumulated duration of successive FTCs & $1 / 4$ \\
\hline & \multirow{5}{*}{$\begin{array}{l}\text { Temporary work agency } \\
\text { employment }\end{array}$} & Types of work for which is legal & $1 / 3$ \\
\hline & & Restrictions on number of renewals & $1 / 6$ \\
\hline & & Maximum cumulated duration & $1 / 6$ \\
\hline & & Information requirements and authorization & $1 / 6$ \\
\hline & & Fair treatment & $1 / 6$ \\
\hline \multirow{4}{*}{$\begin{array}{l}\text { Collective } \\
\text { dismissals }\end{array}$} & & Definition of collective dismissal & $1 / 4$ \\
\hline & & Additional notification obligations & $1 / 4$ \\
\hline & & Additional deadlines & $1 / 4$ \\
\hline & & Other specific costs for employers & $1 / 4$ \\
\hline
\end{tabular}

Table 3. OECD model of EPL

Source: OECD (2014)

In summary, we have decided to present more fully the models that have been developed by international organizations, which are consulted by many international policy makers, scientists and lawyers in the field of labour. However, it cannot be overlooked that other researchers have also developed models measuring employment protection, as did Deakin et al. (2009) of the Center for Business Research (CBR), which built their own model of analysis of employment protection legislation through 
the evaluation of 10-12 variables on a sample of 25 countries between 1995 and 2005. Block et al. (2003) also constructed an indicator based on 10 variables: minimum wage, overtime, paid time-off, unemployment insurance, workers' compensation, collective bargaining, discrimination in employment, unjust dismissal, occupational health and safety, and notices for large-scale layoffs or plant closures in order to assess the strictness of labour standards in the United States and the European Union (EU).

\section{Some theoretical analysis}

Researchers have attempted to measure the impact of EPL on various economic indicators such as unemployment, employment rate, labour mobility, productivity, innovation to assess the level of accountability of this institution (employment protection legislation) in the efficiency of the labour market. Among them, Boeri and Garibaldi (2007) demonstrated, by using a dynamic model of labour demand, that the transition from a system where the EPL is rigid to "two-tier" regime increased employment growth. These "two-tier" reforms, also referred to as "at the margin", were characterized by liberalization of temporary contracts (specific contracts) while maintaining unchanged protection on permanent contracts (open-end contracts). Kugler and St. Paul (2004) also provide theoretical results related to the impact of strict EPL on the selection of employees when hiring. The authors point out that the higher the redundancy costs are, the more firms tend to discriminate in hiring unemployed jobseekers.

Other researchers (Postel-Vinay \& Saint-Martin, 2004) also found that the EPL can create a feeling of insecurity among all employees. Indeed, when EPL is strict, it limits the reallocation of labour (market rigidity), which implies that employees cannot expect to easily find a new job when they are dismissed, and thus maintain the unemployed status for a long period of time (Blanchard \& Wolfers, 2000; L'Haridon \& Malherbet, 2003). However, Belot et al. (2007) indicate that when severance pay is high, workers tend to invest more efforts in their work since they hold a job security (Suedekum \& Ruehmann, 2003).

Finally, some research has also been conducted on the effects of EPL on productivity levels. In this sense, Poschke (2009) finds that the firing costs not only create poor reallocation of labour, but also discourage the exit of less productive firms. Specifically, the author argues that when firms leaving the market are under the rules governing the costs of layoffs, these costs are perceived as an exit tax.

\section{Empirical results validate the theoretical analysis}

In the literature, we find that the results of the empirical studies point in the same direction in general as the results of the theoretical studies cited above. Among others, Lazear (1990) argues, using data from 22 developed countries between 1956 and 1984, that greater rigour on redundancy compensation has the effect of reducing the employment-population ratio. Specifically, the passage of any requirement for severance pay to the obligation of compensation, representing three months' salary for an employee with seniority of 10 years, would reduce the employment-population ratio of about $1 \%$. More recently, Di Tella and McCulloch (2005) have shown that if France would have a similar level of market flexibility to the United States, the employment rate would increase by $1.5 \%$ in the short term and $3.6 \%$ in the long term. 
With respect to the mobility of the workforce, Millán et al. (2013), based on data ranging from 1994 to 2001 from the European Community Household Panel, have shown that EPL has a negative impact on the probability that an individual goes from self-employed to employer (with employees under his responsibility) because of the high costs of hiring in the context of strict EPL. Specifically, they have found that a decrease of 0.43 in the EPL indicator increases the probability of hiring new employees by $2.9 \%$ (Boeri \& Jimeno, 2005). Haltiwanger et al. (2014) have also reach the result that a strict regulation of layoffs and hiring would reduce the efficiency of job reallocation, and particularly in industries where job turnover is high.

In terms of productivity, Van Schaik and Van Klunbert (2013) point out, by using data between 1960 and 2005 from 21 OECD countries, that a highly protective EPL now may not be as relevant and adapted to the market as it once was, since it impedes the productivity largely driven by innovation. The study of Auer et al. (2005) provides a different light on the link between EPL and productivity based on the age of the workers. The authors show a clear positive and significant correlation between EPL strictness and the proportion of workers with seniority of 10 years (Muller \& Berger, 2013).

\section{METHODOLOGY}

As explained in the previous section, the OECD analysis model focuses primarily on layoffs and the use of temporary contracts (see table 3). However, although the guidance associated with layoffs and temporary contracts may be particularly restrictive in some countries, we believe it is important to include other mechanisms related to employment adjustments whose contours are also provided by the regulatory and administrative framework. Consequently, we believe that the evaluation of the strictness of voluntary departure plan and work-sharing (other employment adjustment modes) will lead to a model which is more comprehensive and representative of the constraints imposed on employers in terms of the obligations under the employment protection. We followed the same methodology used by the OECD in the construction of measurement scales and the choice of subcomponents in order to maintain continuity in the model (OECD, 2014). The measurement scales that will be presented will retain their amplitudes from zero to six and the assertions of each of the scales are graduated according to the level of constraint and costs imposed on the employer for each condition association with job protection, which respect the analytical framework adopted by the OECD.

\section{Introduction of a new component}

We have identified four dimensions that constitute the "voluntary departure": the types of eligible contracts, compensation, notification requirements, and employment support obligation. It is important to mention that the choice of these four variables is not random and was done according to the following three criteria: the variables had to be obligations regulated by the legal or administrative framework, they should also have the capacity to impose costs on the employer and, finally, they had to allow a comparative analysis among the countries under study in order to avoid assessment of discriminatory data. For each dimension, we established a grid that shows the various scenarios. Table 4 summarizes all the cases expected for the "voluntary departure". 


\begin{tabular}{|c|c|c|}
\hline Dimension & Grid & Score \\
\hline \multirow{3}{*}{$\begin{array}{l}\text { Types of eligible } \\
\text { contracts } \\
(\text { Scale } 0-2 \times 3)\end{array}$} & The voluntary departure may apply to all types of contracts & 0 \\
\hline & The voluntary departure may apply only to regular contracts and temporary contracts. & 1 \\
\hline & The voluntary departure is only for regular contracts. & 2 \\
\hline \multirow{3}{*}{$\begin{array}{l}\text { Compensation } \\
\text { (Scale } 0-2 \times 3)\end{array}$} & No obligation to pay compensation. & 0 \\
\hline & The compensation must meet a minimum. & 1 \\
\hline & $\begin{array}{l}\text { The compensation may not be less than the legal allowance provided for economic } \\
\text { redundancy. }\end{array}$ & 2 \\
\hline \multirow{4}{*}{$\begin{array}{l}\text { Notification } \\
\text { requirements } \\
\text { (Scale } 0-3 \times 2)\end{array}$} & $\begin{array}{l}\text { When oral notification is sufficient to inform the employee of the voluntary departure } \\
\text { opportunities. }\end{array}$ & 0 \\
\hline & $\begin{array}{l}\text { When the employer must inform the employee in writing of the voluntary departure } \\
\text { opportunities. }\end{array}$ & 1 \\
\hline & When a third party must be informed. & 2 \\
\hline & $\begin{array}{l}\text { When the employer cannot proceed with the implementation of the voluntary departure } \\
\text { plan without the consent of a third party. }\end{array}$ & 3 \\
\hline \multirow{3}{*}{$\begin{array}{l}\text { Employment } \\
\text { Support } \\
\text { Obligation } \\
\text { (Scale } 0-2 \times 3)\end{array}$} & $\begin{array}{l}\text { When there is no obligation for the employer to offer employment support for em- } \\
\text { ployees leaving voluntarily. }\end{array}$ & 0 \\
\hline & $\begin{array}{l}\text { When outplacement assistance and/or rehiring priority must be offered to employees } \\
\text { leaving voluntarily }\end{array}$ & 1 \\
\hline & $\begin{array}{l}\text { When the voluntary departure must follow, in certain circumstances, a job preservation } \\
\text { plan }\end{array}$ & 2 \\
\hline
\end{tabular}

Table 4. The dimensions of the subcomponent "Voluntary Departure"

Regarding the first dimension "types of eligible contracts", we gave a score of " 0 " to the statement "the voluntary departure may apply to all types of contracts" because, in these circumstances, the employer has the flexibility and freedom to identify eligible employees for voluntary dismissal plan without any regulation constraints. In contrast, we have allocated the score " 2 " to the statement "the voluntary departure is only for regular contracts". Finally, to be consistent with the OECD's methodology and to assess these dimensions on a scale from 0 to 6, we assigned a scale of 0-2 multiplied by 3 or, in some cases, a scale of 0-3 multiplied by 2 . As you will see, we have applied the same methodology with the dimensions for work-sharing.

As to compensation, the Canadian legislation imposes no obligation on the employer to pay compensation to workers who voluntarily leave (Government of Canada, 2016). Our analysis has led us to include three levels in the dimension of compensation. Thus, we assigned the lowest score, "0", to the statement "no obligation to pay compensation". In addition, when the compensation established by the legislation, for an employee leaving voluntarily, cannot be less than the legal allowance provided for redundancy, the statement gets the score "2".

In general, the voluntary departure also requires notification obligations. Indeed, the employer has to inform employees of the opportunities to voluntarily leave through amicable separation. However, the legislative framework of this notification may vary with the country. In Canada, employers must not only inform the employee in writing of the possibility of a voluntary departure through, for example, a letter, a notice or a memo, but they must also inform a third party, such as labour authority, in order to ensure that the employee can receive employment-insurance benefits (Government of Canada, 2016; Niel, 2013). 
Finally, with respect to the fourth dimension (obligations relating to employment support) in Canada, the employer is not required by law or administrative authorities to offer employment support to an employee who has voluntarily left through a voluntary plan (Government of Canada, 2016). However, in other cases, it can be required from the employer to offer outplacement assistance and/or rehiring priority to the employee who has voluntarily left.

We have also identified five dimensions constituting this subcomponent: the maximum initial period for work-sharing granted by public authorities, obligations recovery, training obligations, the obligation of fair treatment in the reduced hours and finally, compensation. As for the "voluntary departure", we selected variables based on the same criteria. Table 5 summarizes all the cases expected for the "work-sharing".

\begin{tabular}{|c|c|c|}
\hline Dimension & Grid & Score \\
\hline \multirow{3}{*}{$\begin{array}{c}\text { Maximum } \\
\text { initial period } \\
(\text { Scale } 0-2 \times 3)\end{array}$} & Maximum initial period of over 12 months & 0 \\
\hline & Maximum initial period of six to 12 months & 1 \\
\hline & Maximum initial period of six months or less & 2 \\
\hline \multirow{3}{*}{$\begin{array}{c}\text { Obligations } \\
\text { recovery } \\
\text { (Scale } 0-2 \times 3)\end{array}$} & Non-mandatoryrecovery plan & 0 \\
\hline & Mandatory recovery plan in certain circumstances & 1 \\
\hline & Mandatoryrecovery plan & 2 \\
\hline \multirow{3}{*}{$\begin{array}{c}\text { Training } \\
\text { obligations } \\
\text { (Scale } 0-2 \times 3)\end{array}$} & No training required & 0 \\
\hline & Training obligations in certain circumstances & 1 \\
\hline & Training obligations & 2 \\
\hline \multirow{2}{*}{$\begin{array}{l}\text { Fair treatment } \\
\text { (Scale } 0-6)\end{array}$} & No obligation for the equitable sharing of work & 2 \\
\hline & Obligation of fair work-sharing & 4 \\
\hline \multirow{2}{*}{$\begin{array}{c}\text { Compensation } \\
\text { (Scale 0-6) }\end{array}$} & The nonworking hours are supported by a public program & 2 \\
\hline & The nonworking hours are paid by the employer and the government & 4 \\
\hline
\end{tabular}

Table 5. The dimensions of the subcomponent "Work-Sharing"

First, the maximum initial period is the maximum time initially granted to the firm to recover. This varies somewhat depending on the country. In Canada, that period is capped at 26 weeks. In most cases, this period may be extended following a request for an extension made by the employer to the public authorities (Government of Canada, 2016).

As for the obligations of recovery, we assigned the lowest score to the statement "not mandatory recovery plan" since in this case, the employer has no obligation to prepare a recovery plan for the firm and present it to the administrative authority.

Regarding training obligations, Portugal requires from the employer to provide mandatory training for workers in short-time working (Hijzen \& Venn, 2011), whereas, in other countries, such as France, training is mandatory only in special circumstances. In Canada, there is no obligation for the employer to offer training which is rather optional, and therefore left to the discretion of the employer (Government of Canada, 2016).

The fourth dimension is "fair treatment". Indeed, in Canada, the employer must ensure not only reduced work hours fairly, but also make sure to spread the available work hours equitably, regardless 
of seniority clauses in collective agreements. In addition, if during the period of the work-sharing agreement the level of labour increases, overtime should be divided equally between employees (Government of Canada, 2016). However, we do not always find that fair treatment in all countries. For example, in France and Belgium, the administrative or regulatory authority does not state explicitly that requirement.

In Canada, nonworking hours are paid through the employment-insurance plan and the employer is not constrained to pay compensation. However, the employer is subjected to a rigorous audit of its recovery efforts and should, in particular, demonstrate that he operates its business for at least two years (Government of Canada, 2016). In other cases, as in France, the employer is responsible for paying compensation for work-sharing workers and the state offers a partial refund.

As discussed above, we believe that assign weighting 5/12 to "regular contracts" and "temporary contract" and 2/12 to "collective dismissals" for all countries without modulation, as does the OECD, does not provide indicators that do not exactly represent the reality and dynamics of the labour market.

\section{Regular and Temporary Contracts}

First, following our analysis of trends in temporary and permanent employment in Canada (Statistics Canada, 2016b), we find that, from 2005 to 2015, the share of permanent and temporary employment represents $86.65 \%$ and $13.35 \%$ respectively of the total employment. Although the evolution of temporary and permanent employment is cyclical, the wide gap observed in their share in the Canadian labour market leads us to reasonably believe that attributing the same weighting to the components' "regular contracts" and "temporary contracts" could result in a biased assessment of the EPL indicator. As a result, we propose to give the weighting of 3/12 to "temporary contract" and of 6/12 to "regular contracts" which would make the synthetic indicator more suited to the composition of the labour market.

\section{Collective dismissals}

To assess the extent of redundancies, we relied on the Canadian study produced by Statistics Canada (Morissette et al., 2007) using data from the Longitudinal Worker File. Data from this study allowed us to measure the proportion of workers affected by economic collective redundancy $(0.25 \%$ in 2002$)$ during an economically stable period (Statistics Canada, 2004; 2011).

Note that collective dismissals represent a small share of permanent layoffs in Canada $(8.77 \%$ in 2002) (layoffs occur for any reason, including temporary employment cessation), hence the need to give it a much lower weighting to that attributed to the components' "regular contracts" and "temporary contracts".

\section{Work-sharing and Voluntary departure}

To properly integrate this new component (which includes work-sharing and voluntary departure) of the analysis model, we will assign a weighting of its weight on the labour market.

Using the Statistics Canada database (2016a), we have calculated the rate of work-sharing benefits as presented in Figure 1. The latter allows us to see that the evolution of benefits is counter-cyclical; an increase in a recession and a decline in a growth period. Indeed, the lowest benefit rate was recorded 
in $2006(0.13 \%)$ and the highest was in 2009 (3.47\%) at the heart of the latest economic crisis. However, between 2002 and 2015, the average benefit rate for work-sharing amounted to $0.32 \%$. Therefore, this finding suggests that this mechanism, in general, is not particularly used when we compare the data with those concerning individual dismissals.

As for the "voluntary departure", it was particularly difficult to obtain data. However, we assume that it would follow a similar pattern to "work-sharing" since it is generally used to reduce the number of layoffs. We then assign a weight (1.5/12) to the components "collective dismissals" and "work-sharing and voluntary departure" (Venn, 2009).

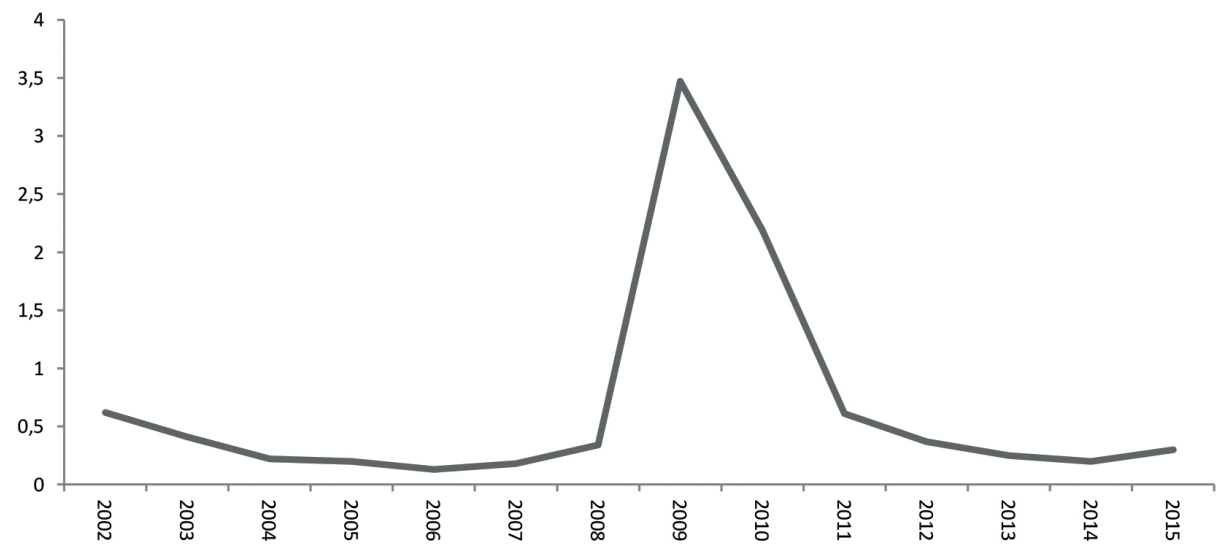

Figure 1: Benefit rate (\%) for work-sharing in Canada from 2002 to 2015

Source:Statistics Canada data. Table 282-0002 - Labour Force Survey (LFS) estimates by sex and detailed age group, annual (persons unless otherwise noted), CANSIM (database). (Accessed at: June 30, 2016)

\section{RESULTS AND DISCUSSION}

We will now measure the strictness of "voluntary departure" and "work-sharing" for Canada. To do this, first, we begin by assessing their dimensions.

Regarding the "voluntary departure" and when we analyze the law and administrative obligations under the legislation, it is not indicated that this mechanism is only open to employees of a specific category (Government of Canada, 2016). So that is why we assign the score "0" for this dimension. With respect to the "compensation" dimension, in Canada, the legislative and administrative authorities do not mention obligations for the employer to pay compensation as a result of a voluntary departure agreement. Therefore, we place the score " 0 " to this dimension also. When we examine the dimension "notification obligations", the given rating is different from the first two dimensions. Indeed, in Canada, the employer must not only inform in writing the employees of voluntary departure opportunities but also notify a third party, so that employees who left voluntarily can benefit from employment-insurance benefits (Government of Canada, 2016). It is for these reasons that we allocate the score "2" to this dimension. As for the employment support obligation, the employer is not required by law or administrative authorities to provide assistance to employment to employees who use "voluntary departure" (Government of Canada, 2016). It is especially through the employment-insurance program that the worker may receive this type of aid. We attribute the score " 0 " for this dimension. 
Furthermore, we rebuilt the OECD formula which allows calculating the synthetic indicator of each country (OECD, 2014). We will then use the following expression:

$$
i=((c 1 * e 1) * p 1)+((c 2 * e 2) * p 2)+((c 3 * e 3) * p 3)+((c 4 * e 4) * p 4)
$$

\section{i: Indicator obtained for the sub-component}

$\mathbf{c}_{1}$ : Score obtained for the first dimension

$\mathbf{c}_{2}$ : Score obtained for the second dimension

$c_{3}$ : Score obtained for the third dimension

$\mathbf{c}_{4}$ : Score obtained for the fourth dimension

$\mathbf{e}_{1}$ : Graduation of the measurement scale for the first dimension

$\mathbf{e}_{2}$ : Graduation of the measurement scale for the second dimension

$\mathbf{e}_{3}$ : Graduation of the measurement scale for the third dimension

$\mathbf{e}_{4}$ : Graduation of the measurement scale for the fourth dimension

$\mathbf{p}_{1}$ : Weighting for the first dimension

$\mathbf{p}_{2}$ : Weighting for the second dimension

$\mathbf{p}_{3}$ : Weighting for the third dimension

$\mathbf{p}_{4}$ : Weighting for the fourth dimension

Applying this formula to the "voluntary departure", we get the indicator $\mathrm{i}_{\mathrm{pdv}}$ :

$$
i_{p d v}=((0 * 3) * 1 / 4)+((0 * 3) * 1 / 4)+((2 * 2) * 1 / 4)+((0 * 3) * 1 / 4)=1
$$

Canada secured the result of 1 on a scale of 6 for its rigour on "voluntary departure". This result is also registered in the objective pursued by the legislature to give more flexibility to the employer when faced with restructuring (Government of Canada, 2015).

Regarding "work-sharing", when we look at the study of the maximum initial period, we note that in Canada, this term is limited to 26 weeks, which represents a little more than six months (Government of Canada, 2016). This brings us to assign the score " 1 " on the measurement scale constructed for this dimension. As for the obligations of recovery, the plan must be submitted to the competent administrative authorities to register the work-sharing program (Government of Canada, 2016). This strict framework may be explained by the fact that the employment-insurance program completely covers the allowances for short-time working. This requirement of the recovery plan, therefore, ensures that the firm will implement concrete actions within a reasonable time to remedy the situation. Our analysis thus leads us to give score "2" to this dimension. With respect to training obligations, it is not mandatory for the employer to provide this type of assistance for employees on work-sharing. This is quite optional and the decision rests in the hands of the employer and the worker (Government of Canada, 2016). That is why we allocate the score " 0 " for this dimension. Regarding the "fair treatment" dimension, the employer must actually ensure equitable sharing of work hours among workers (Government of Canada, 2016), hence the allocation of the score "4". Finally, for the last dimension "compensation", we find through our analysis that the nonworking hours are supported by a state program (employment insurance) and the employer is not required to pay compensation to workers affected by partial unemployment, which brings us to give score " 2 " for that dimension. 
We can now calculate the indicator, iws, for "work-sharing" according to the OECD formula:

$$
i_{w s}=(1 * 3) * 1 / 5+(2 * 3) * 1 / 5+(0 * 3) * 1 / 5+(4 * 1 / 5)+(2 * 1 / 5)=3
$$

We can also calculate the synthetic indicator, $i$, revised for Canada, following indicators obtained for "voluntary departure" and "work-sharing" and using the new weights given to "regular contracts", "temporary contract" and to "collective dismissals". Using the same formula, we obtain:

$$
i_{s}=(6 / 12 * 0.92)+(3 / 12 * 0.21)+(1.5 / 12 * 2.97)+(1.5 / 12 * 2)=1.13
$$

Table 6 presents a detailed compilation of the OECD model taking into account our adjustments.

\begin{tabular}{|c|c|c|c|c|}
\hline \multirow[t]{2}{*}{ Level 4} & \multirow[t]{2}{*}{ Level 3} & Level 2 & Level 1 & \multirow{2}{*}{ 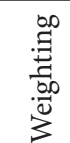 } \\
\hline & & \multicolumn{2}{|c|}{ Scale (0 to 6$)$} & \\
\hline \multirow{34}{*}{ 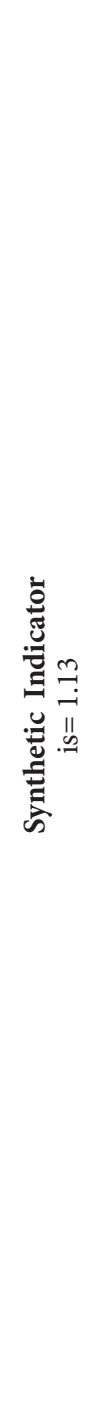 } & \multirow{13}{*}{$\begin{array}{c}\text { Regular } \\
\text { contracts } \\
(6 / 12)\end{array}$} & \multirow{2}{*}{ Constraints procedures } & Notification procedures & $1 / 2$ \\
\hline & & & Delay opening of the notice period & $1 / 2$ \\
\hline & & \multirow{6}{*}{$\begin{array}{l}\text { Notice and severance pay } \\
\text { for individual dismissal } \\
\text { without fault }\end{array}$} & Notice period after 9 months & $1 / 7$ \\
\hline & & & Period of notice after 4 years & $1 / 7$ \\
\hline & & & Period of notice after 20 years & $1 / 7$ \\
\hline & & & Severance pay after 9 months & $4 / 21$ \\
\hline & & & Severance pay after 4 years & $4 / 21$ \\
\hline & & & Severance pay after 20 years & $4 / 21$ \\
\hline & & \multirow{5}{*}{ Difficulty of dismissal } & Definition of unfair dismissal & $1 / 5$ \\
\hline & & & Duration of the trial period & $1 / 5$ \\
\hline & & & Compensation & $1 / 5$ \\
\hline & & & Reinstatement & $1 / 5$ \\
\hline & & & Maximum time for claim & $1 / 5$ \\
\hline & \multirow{8}{*}{$\begin{array}{l}\text { Temporary } \\
\text { contract } \\
(3 / 12)\end{array}$} & \multirow{3}{*}{$\begin{array}{l}\text { Fixed-term contracts } \\
\text { (FTC) }\end{array}$} & Should the use of FTC is justified & $1 / 2$ \\
\hline & & & Maximum number of successive FTC & $1 / 4$ \\
\hline & & & Maximum cumulated duration of successive FTC & $1 / 4$ \\
\hline & & \multirow{5}{*}{$\begin{array}{c}\text { Temporary work agency } \\
\text { employment }\end{array}$} & Types of jobs for which is legal & $1 / 3$ \\
\hline & & & Restrictions on the number of renewals & $1 / 6$ \\
\hline & & & Maximum cumulated duration & $1 / 6$ \\
\hline & & & Information requirements and authorization & $1 / 6$ \\
\hline & & & Fair treatment & $1 / 6$ \\
\hline & \multirow{4}{*}{$\begin{array}{c}\text { Collective } \\
\text { dismissals } \\
(1.5 / 12)\end{array}$} & & Definition of collective dismissal & $1 / 4$ \\
\hline & & & Additional notification obligations & $1 / 4$ \\
\hline & & & Additional deadlines & $1 / 4$ \\
\hline & & & Other specific costs for employers & $1 / 4$ \\
\hline & \multirow{9}{*}{$\begin{array}{c}\text { Other } \\
\text { employment } \\
\text { adjustment } \\
\text { modes } \\
(1.5 / 12)\end{array}$} & Voluntary & Types of eligible contracts & $1 / 4$ \\
\hline & & departure & Compensation & $1 / 4$ \\
\hline & & $(1 / 2)$ & Notification requirements & $1 / 4$ \\
\hline & & $\mathbf{i}_{p d v}=1$ & Employment Support Obligation & $1 / 4$ \\
\hline & & \multirow{5}{*}{$\begin{array}{l}\text { Work-sharing } \\
\quad(1 / 2) \\
\mathbf{i}_{w s}=3\end{array}$} & Maximum initial period & $1 / 5$ \\
\hline & & & Obligations recovery & $1 / 5$ \\
\hline & & & Training obligations & $1 / 5$ \\
\hline & & & Fair treatment & $1 / 5$ \\
\hline & & & Compensation & $1 / 5$ \\
\hline
\end{tabular}
Note that the OECD base model (without adjustments) reaches a synthetic indicator of 0.97 . 
It is, therefore, clear from these results that the integration of other employment adjustment modes and the revision of weights are rising the Canadian synthetic indicator. Indeed, our synthetic indicator amounted to 1.13 while that of the OECD is 0.97 . The particularly high indicator for "work-sharing" can be explained by the fact that the government plays an important role in the support offered to employees in partial unemployment. Indeed, firms have no obligation for compensation and training with regard to work-sharing workers since the employment-insurance program fully covers the severance pay and guarantees help in the search for jobs to recipients of employment-insurance benefits. Therefore, as the employer has little responsibility in these matters, the legislature imposes in return strict monitoring in regard to the recovery of the firm and fair treatment of employees affected by this mechanism. In addition, although having scored below the "work-sharing", the "voluntary departure" also has a slightly higher synthetic indicator (1.00) than "regular contracts" (0.92) and "temporary contracts" (0.21). This can be explained primarily by the "notification obligations" dimension which has received a score of 2 . In short, the consideration of new items and the review of the weights with slightly rising the Canadian synthetic indicator show that the assessment of the constraints imposed on employers during layoffs and use of temporary contracts may understate the degree of EPL strictness for Canada.

The addition of two new items to the OECD analysis grid and the revision of weights, increasing the Canadian synthetic indicator, may also slightly change the overall ranking of countries made by the OECD. Our findings could also have implications in terms of public policy. Indeed, poor assessment of the EPL strictness skews the meaning and direction of reforms to stimulate job creation.

Furthermore, and although our indicator is revised upward, it remains important to consider other alternatives to better protect workers against the economic uncertainty. In this perspective, lifelong training is an option that should be seriously considered in the formulation of Canadian public policy so that workers can find a job efficiently following a layoff and have a human capital which is not only associated with the firm but a capital that is transportable and maintaining their employability. France has also begun the step in this direction by adopting in 2009 the individual right to training (Pereira, 2010).

\section{CONCLUSIONS}

The proliferation of EPL analysis models was caused by a significant and justified concern about the rigidity of the labour market, particularly in a recession, and the presence of institutional sclerosis in some countries. Thus, it is important to consider all the employment protection measures that impose constraints on employers in adjusting their workforce. We have shown that the inclusion of two mechanisms (voluntary departure and work-sharing) in evaluating the EPL strictness has increased the composite indicator for Canada.

Certainly, our approach is not perfect. Besides, our measurement scales associated with the "voluntary departure" and "work-sharing" deserve to be deepened in their international coverage. In other words, when we made them, we focused on a few countries, but to make the scales even more reliable and valid, we should analysetheir terms in all OECD countries. In addition, in our analysis, we relied on the legislative and administrative data issued by public authorities. It would then be appropriate to broaden our thinking to incorporate jurisprudence aspects to capture all legal information related to mechanisms that caught our attention in this article. 


\section{REFERENCES}

Adams, Z., Bastani, P., Bishop, L., \& Deakin, S. (2017). The CBR-LRI Dataset: Methods, Properties and Potential of Leximetric Coding of Labour Laws. International Journal of Comparative Labour Law and Industrial Relations, 33(1), 59-92. DOI: 10.17863/CAM.8220

Amine, S., Chatraoui, A., Gravel, F., \& Lebon, I. (2007). Productivité et risque de destruction des emplois : un argument favorable à l'instauration d'une taxe sur les licenciements. Revue d'économie politique, 117(6), 921936. DOI: $10.3917 /$ redp.176.0921

Auer, P., Berg, J., \& Coulibaly, E.I. (2005). Une main-d'œuvre stable est-elle bonne pour la productivité? Revue internationale du Travail, 144(3), 335-361. DOI: 10.1111/j.1564-913X.2005.tb00480.x

Belot, M., Boone, J., \& Van Ours, J. (2007). Welfare-Improving Employment Protection. Economica, 74(295), 381-396. DOI: 10.1111/j.1468-0335.2006.00576.x

Bisignano, M. (2014). Contester, retarder ou empêcher les licenciements via le chômage partiel? Travail et Emploi, 2014/1(137), 69-84.

Blanchard, O., \& Tirole, J. (2003). Protection de l'emploi et procédures de licenciement. Paris: La Documentation Française.

Blanchard, O., \& Wolfers, J. (2000). The Role of Shocks and Institutions in the Rise of European Unemployment: the Aggregate Evidence. The Economic Journal, 110(462), 1-33. DOI: 10.1111/1468-0297.00518

Block, R. N., Berg, P., \& Roberts, K. (2003). Comparing and quantifying labour standards in the United States and the European Union. International Journal of Comparative Labour Law and Industrial Relations, 19(4), 441-468.

Block, R. N. (2007). Indicators of labour standards: an overview and comparison. In Qualitative Indicators of Labour Standards (pp. 27-56). Dordrecht, The Netherlands: Springer.

Boeri, T., \& Garibaldi, P. (2007). Two Tier Reforms of Employment Protection: A Honeymoon Effect? The Economic Journal, 117(521), 357-385. DOI: 10.1111/j.1468-0297.2007.02060.x

Boeri, T., \& Jimeno, J. (2005). The Effects of Employment Protection: Learning from Variable Enforcement. European Economic Review, 49(8), 2057-2077. DOI: 10.1016/j.euroecorev.2004.09.013

Bourguignon, R. \& Garaudel, P. (2015). L’appropriation de la règle de droit : impératif de sauvegarde de l'emploi et dispositifs de départs volontaires. GRH, 3(16), 41-62. DOI: 10.3917/grh.153.0041

Deakin, S., Armour J., \& Singh, A. (2009). Law, Finance and Development Indices, 1970-2005. UK Data Service. DOI: $10.5255 /$ UKDA-SN-6260-1

Deslauriers, J., Dostie, B., \& Gagné, R. (2009). L'impact économique de la législation du marché du travail. Montréal: Centre sur la productivité et la prospérité. Retrieved Jun 6, 2017, from http://cpp.hec.ca/cms/assets/ documents/recherches/reglementations-du-marche-du-travail_octobre-2009.pdf

Di Tella, R., \& MacCulloch, R. (2005). The Consequences of Labour Market Flexibility: Panel Evidence Based on Survey Data. European Economic Review, 49, 1225-1259.

Government of Canada. (2015). Digest of Benefit Entitlement Principles. Retrieved Jun 6, 2017, from https://www. canada.ca/en/employment-social-development/programs/ei/ei-list/reports/digest.html

Government of Canada. (2016). Work Force Reduction program due to downsizing. Retrieved Jun 6, 2017, from https://www.canada.ca/en/employment-social-development/programs/ei/ei-list/ei-employers-workforcereduction.html

Government of Canada. (2016). Work-Sharing. Retrieved Jun 6, 2017, from https://www.canada.ca/en/employment-social-development/services/work-sharing.html

Haltiwanger, J., Scarpetta, S., \& Schweiger, H. (2014). Cross country differences in job reallocation: The role of industry, firm size and regulations. Labour Economics, 26, 11-25. DOI: 10.1016/j.labeco.2013.10.001

Hijzen, A., \& Venn, D. (2011). The Role of Short-Time Work Schemes during the 2008-09 Recession. Paris: OECD Publishing. 
International Labour Organization. (2013). Employment protection legislation database: EPLex. Geneva: ILO.

Kirat, T. (2006). Les indicateurs de protection de l'emploi (OCDE et Banque Mondiale). Retrieved Jun 6, 2017, from https://halshs.archives-ouvertes.fr/halshs-00096054

Kugler, A., \& Saint-Paul, G. (2004). How Do Firing Costs Affect Worker Flows in a World with Adverse Selection. Journal of Labour Economics, 22(3), 553-584. DOI: 10.1086/383107

Lazear, E. P. (1990). Job Security Provisions and Employment. The Quarterly Journal of Economics, 105(3), 699726. DOI: $10.2307 / 2937895$

L'Haridon, O., \& Malherbet, F. (2003). Protection de l'emploi et performance du marché du travail. Commentaire de Bertrand Martinot. Revue française d'économie, 17(4), 21-83. DOI: 10.3406/rfeco.2003.1472

Martin, J. (2013). La pertinence des indicateurs internationaux de protection de l'emploi. Communication présentée au séminaire Politiques de l'emploi, Paris.

Martin, J., Du Marais, B., \& Dehaze, A. (2013). Mise en perspective des difficultés dans la mesure du droit du travail: constats et perspectives économiques. Direction générale du Trésor. Retrieved Jun 6, 2017, from https://www. tresor.economie.gouv.fr/Ressources/File/405741

Millán, A., Millán, J. M., Román, C., \& Van Stel, A. (2013). How does employment protection legislation influence hiring and firing decisions by the smallest firms? Economics Letters, 121(3), 444-448. DOI: 10.1016/j. econlet.2013.09.021

Morissette, R., Zhang, X., \& Frenette, M. (2007). Les pertes de gains des travailleurs déplacés: données canadiennes extraites d'une importante base de données sur les fermetures d'entreprises et les licenciements collectifs. Retrieved Jun 6, 2017, from https://www.statcan.gc.ca/pub/11f0019m/11f0019m2007291-fra.htm

Muller, L., \& Berger, D. P. (2013). The Impact of a Country's Employment Protection Legislation on its Economic Prosperity. International Journal of Humanities and Social Science, 3(12), 1-13.

Niel, S. (2009). Comment développer un plan de départ volontaire pour motif économique? Les cahiers du DRH, 155, 27-33.

Niel, S. (2013). Que doit désormais contenir le PDV? Les Cahiers du DRH, 202.

Niel, S., \& Hautefort, M. (2015). Le licenciement économique (2e édition). France: Éditions Lamy.

OECD. (1990). Employment protection and Labour Market Performance. Retrieved Jun 6, 2017, from https:// www.oecd.org/employment/emp/2079974.pdf

OECD. (1993). Key Issue for Labour Market and Social Policies. Retrieved Jun 6, 2017, from https://www.oecd. org/els/emp/2485426.pdf

OECD. (2012). Economic policy reforms 2012: Going for growth. Paris: OECD. DOI: 10.1787/growth-2012-en

OECD. (2013). Protecting jobs, enhancing flexibility: A new look at employment protection legislation. Paris: OECD. DOI: 10.1787/empl_outlook-2013-6-en

OECD. (2014). OECD Indicators of Employment Protection. Paris: OECD.

Pereira, B. (2010). Libéralisation du marché du travail : vers une flexisécurité à la française. Management \& Avenir, 4(34), 81-106. DOI: $10.3917 /$ mav.034.0081

Poschke, M. (2009). Employment protection, firm selection, and growth. Journal of Monetary Economics, 56(8), 1074-1085. DOI: 10.1016/j.jmoneco.2009.10.013

Postel-Vinay, F., \& Saint-Martin, A. (2004). Comment les salariés perçoivent-ils la protection de l'emploi? Économieet Statistiques, 372, 41-59. DOI: 10.3406/estat.2004.7266

Statistics Canada. (2004). Longitudinal Worker File (LWF). Retrieved Jun 6, 2017, from http://www5.statcan. gc.ca/olc-cel/olc.action?objId=75C0013\&objType $=22 \&$ lang $=$ en\&limit $=0$

Statistics Canada. (2011). Longitudinal Employment Analysis Program (LEAP). Retrieved Jun 6, 2017, from http:// www23.statcan.gc.ca/imdb/p2SV.pl?Function=getSurvey\&SDDS=8013

Statistics Canada. (2016a). Labour force survey estimates (LFS), by sex and detailed age group. Retrieved Jun 6, 2017, from http://www5.statcan.gc.ca/cansim/a26?lang=eng\&id=2820227 
Statistics Canada. (2016b). Permanent layoff rates from the CEEDD and SLID, employees aged 18 to 64, by province, 2003 to 2011. Retrieved Jun 6, 2017, from http://www.statcan.gc.ca/pub/11-633-x/2016001/t/tbl10-eng.htm

Suedekum, J., \& Ruehmann, P. (2003). Severance payments and firm-specific human capital. Labour, 17(1), 4762. DOI: $10.1111 / 1467-9914.00221$

Van Schaik, T., \& Van de Klundert, T. (2013). Employment Protection Legislation and Catching-up. Applied Economics, 45(8), 973-981. DOI: 10.1080/00036846.2011.613784

Venn, D. (2009). Legislation, collective bargaining and enforcement: Updating the OECD employment protection indicators. Retrieved Jun 6, 2017, from http://www.oecd.org/employment/emp/43116624.pdf

Werner, E., \& Marx, P. (2009). Le chômage partiel, amortisseur social de la crise? Regards surl'économie allemande, 90, 23-30.

\section{PREGLED OECD INDIKATORA ZAKONA O ZAŠTITI ZAPOŠLJAVANJA ZA PODRUČJE KANADE}

\section{Rezime:}

Počev od ranih devedesetih, Zakon o zaštiti zapošljavanja predstavlja važnu stavku za političke činioce, naročito kada je reč o uticaju ove regulative na zapošljavanje i produktivnost rada. Ova tema privukla je veliku pažnju međunarodnih organizacija koje su kreirale brojne analitičke modele kako bi procenile koliko je ovaj zakon strog u različitim zemljama. Smatramo da su svi do sada razvijeni modeli nepotpuni, uprkos činjenici da pružaju mnoštvo informacija. Svrha ovog rada jeste da predloži uvođenje novih elemenata u model analize koji primenjuje Organizacija za ekonomsku saradnju i razvoj (OECD), a na osnovu iskustva Kanade. Stoga predlažemo da se sintetički (zbirni) pokazatelj Zakona o zaštiti zapošljavanja izmeni, uzimajući u obzir lokalne specifičnosti koje OECD prethodno nije razmatrala.

\section{Ključne reči:}

Zakon o zaštiti zapošljavanja, sintetički indikator, Organizacija za ekonomsku saradnju i razvoj (OECD), dobrovoljni odlazak, podela rada 